\title{
Kidney Neuroendocrine Neoplasm
}

National Cancer Institute

\section{Source}

National Cancer Institute. Kidney Neuroendocrine Neoplasm. NCI Thesaurus. Code C157743.

An epithelial neoplasm with neuroendocrine differentiation that arises from the kidney. It includes well differentiated neuroendocrine tumor, small cell neuroendocrine carcinoma, large cell neuroendocrine carcinoma and parag ang lioma. 